J. Reprod. Fert. (1966) 11, 307-310

BRIEF COMMUNICATION

\title{
LOCAL UTERINE MECHANISMS AFFECTING LUTEAL FUNCTION IN THE SHEEP
}

\author{
R. M. MOOR AND L. E. A. ROWSON \\ A.R.G. Unit of Reproductive Physiology and Biochemistry*, University of Cambridge
}

(Received 27th November 1965)

Summary. The ovary not containing the corpus luteum was removed from each of fifty-two ewes on Day 8 of the cycle. These animals were then allocated to one of the following groups. Group 1: (control) received no further treatment. Group 2: the contralateral uterine horn, i.e. located on the side opposite to the corpus luteum, was removed. Group 3: the ipsilateral uterine horn, i.e. located on the same side as the corpus luteum, was removed.

Neither unilateral ovariectomy alone (Group 1) nor the removal of the contralateral horn (Group 2) affected the length of the post-operative oestrous cycles. In contrast, extirpation of the ipsilateral uterine horn (Group 3) resulted in a significant extension of the oestrous cycle and thus of the life-span of the corpus luteum. The results suggest that the ovaries of the cyclical sheep are probably affected by the uterus in a local manner.

A functional interrelationship is known to exist between the uterus and the corpora lutea in many species including the sheep. It has, for example, been shown by Wiltbank \& Casida (1956) that the regression of the ovine corpus luteum during late dioestrus requires the presence of the uterus. More recent experiments have demonstrated that the removal of the uterus can arrest the involutionary changes in the lutein cells of the sheep even when hysterectomy is carried out at a relatively advanced stage of luteal regression (Moor \& Rowson, 1964). Using partially hysterectomized ewes, Rowson \& Moor (1964) were further able to show that the life-span of the corpus luteum in such animals is directly related to the amount of uterine tissue that has been removed. Little, however, is known of the mechanisms that are involved in the uterine control of luteal function.

The first evidence suggesting that the corpora lutea are influenced by the uterus in a local manner was obtained by du Buisson (1961) from experiments carried out in the pig. A local control of luteal function by the uterus of the guinea-pig has also recently been shown to exist (Fischer, 1965; Bland \& Donovan, 1965). The present study was undertaken to shed some light on the

* Postal address: Animal Research Station, 307 Huntingdon Road, Cambridge. 
mechanisms underlying the interrelationship between the uterus and the corpus luteum of the sheep.

A total of fifty-two multiparous ewes of the Welsh Mountain breed was used. The experiments were carried out during the 1964 to 1965 breeding season, and throughout that period the animals were kept under standard indoor conditions. Oestrus was detected by placing raddled vasectomized rams with the ewes and examining the flock every $12 \mathrm{hr}$ for service marks. The day of onset of oestrus will be referred to as Day 0 of the cycle and all other stages measured from that time.

All ewes were laparotomized on the 8th day after oestrus. From each animal, one ovary, namely that not containing the functional corpus luteum, was removed so as to ensure that all future ovulations would occur in the one ovary only. The corpus luteum in the remaining ovary was marked with animal charcoal for subsequent identification. These unilaterally-ovariectomized animals were then allocated to one of three groups, Group 1 sheep (controls) received no further treatment. In Group 2 the contralateral uterine horn, i.e.

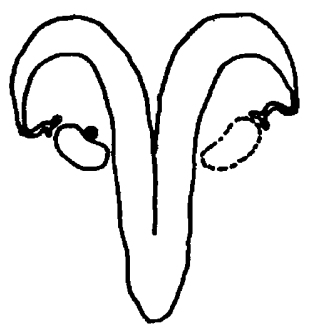

Group 1

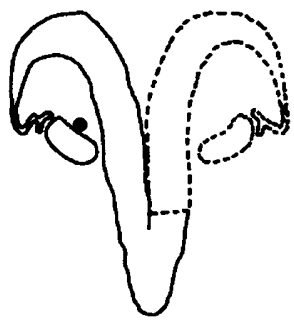

Group 2

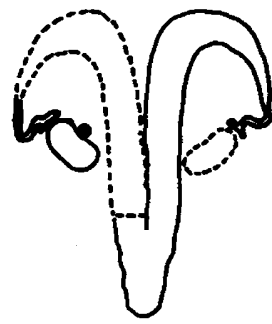

Group 3

Text-Fig. 1. Diagrammatic representation of the surgical procedures carried out in the three groups of sheep. The broken line shows the portion of the uterus and the side of the ovary removed in each animal: Group 1 (control ewes), unilateral ovariectomy only; Group 2, contralateral uterine horn removed plus unilateral ovariectomy; Group 3, ipsilateral horn removed plus unilateral ovariectomy.

the horn located on the side opposite to the corpus luteum, was removed. The ipsilateral uterine horn, i.e. the horn located on the same side as the corpus luteum, was removed from the ewes in Group 3. Particular care was taken during the hysterectomy operation to ensure that the ovarian blood supply was not damaged. The treatments in the three groups of ewes are shown diagrammatically in Text-fig. 1.

The operated ewes were placed with vasectomized rams in order to determine the length of all post-operative oestrous cycles; those ewes which did not show oestrus within 32 days of surgery, i.e. 40 days after the last oestrus, were autopsied and their ovaries examined.

The effect of removing one uterine horn on the length of the oestrous cycles of unilaterally ovariectomized sheep is shown in Table 1. It is evident from the Table that in the control group of ewes (Group 1) the length of the post-operative oestrous cycles, and hence the life-span of the corpora lutea, was not significantly different before and after the removal of the ovary that did not 
contain the corpus luteum. Similarly, in Group 2 composed of twenty ewes, forty-eight out of fifty-three, i.e. $91 \%$, of the post-operative cycles were unaffected by the extirpation of the contralateral uterine horn. The mean length of the oestrous cycles in Group 2 ewes was not significantly different before and after the removal of the contralateral uterine horn. In marked contrast, however, were the results obtained in Group 3, that is in the twenty-two ewes subjected to the removal of the ipsilateral uterine horn. In that group the life-span of the corpora lutea was distinctly extended in twenty-two out of thirty-one, i.e. $71 \%$, of the post-operative oestrous cycles. Ten animals in Group 3 did not show oestrus even after 40 days and in these sheep maintained corpora lutea were found at autopsy.

The results obtained in the present paper suggest that the functional life-span of the corpus luteum in the sheep is, like the pig and guinea-pig, influenced by the non-pregnant uterus in a local manner. Two possible explanations for these findings warrant consideration.

\section{TABLE 1}

LUTEAL FUNCTION IN THE GYCLICAL SHEEP AFTER THE REMOVAL ON THE 8TH DAY AFTER OESTRUS OF ONE UTERINE HORN TOGETHER WITH THE NON-CORPUS LUTEUM BEARING OVARY

\begin{tabular}{|c|c|c|c|c|c|c|c|c|}
\hline \multirow{3}{*}{$\begin{array}{c}\text { Experi- } \\
\text { mental } \\
\text { group }\end{array}$} & \multirow{3}{*}{$\begin{array}{l}\text { Side of ablated } \\
\text { uterine horn } \\
\text { relative to } \\
\text { ovary bearing } \\
\text { the corpus } \\
\text { luteum }\end{array}$} & \multirow{3}{*}{$\begin{array}{l}\text { No. } \\
\text { of ewes/ } \\
\text { group }\end{array}$} & \multicolumn{4}{|c|}{$\begin{array}{c}\text { No. of normal and extended cycles } \\
\text { after operation }\end{array}$} & \multicolumn{2}{|c|}{$\begin{array}{l}\text { Mean length } \pm S . E . \text { of } \\
\text { oestrous cycles }(\text { days })\end{array}$} \\
\hline & & & \multirow{2}{*}{$\begin{array}{l}\text { Total } \\
\text { No. }\end{array}$} & \multirow{2}{*}{$\begin{array}{c}\text { Normal } \\
<19 \\
\text { days }\end{array}$} & \multicolumn{2}{|c|}{ Extended cycles } & \multirow{2}{*}{$\begin{array}{c}\text { Before } \\
\text { operation }\end{array}$} & \multirow{2}{*}{$\begin{array}{c}\text { After } \\
\text { operation }\end{array}$} \\
\hline & & & & & $\begin{array}{l}19 \text { to } 40 \\
\text { days }\end{array}$ & $>40$ days & & \\
\hline $\begin{array}{c}1 \\
\text { (Control) }\end{array}$ & - & 10 & 22 & 22 & 0 & 0 & $16 \cdot 6 \pm 0 \cdot 2$ & $16 \cdot 6 \pm 0 \cdot 3$ \\
\hline $\begin{array}{l}2 \\
3\end{array}$ & $\begin{array}{l}\text { Contralateral } \\
\text { Ipsilateral }\end{array}$ & $\begin{array}{l}20 \\
22\end{array}$ & $\begin{array}{l}53 \\
31\end{array}$ & $\begin{array}{r}48 \\
9\end{array}$ & $\begin{array}{r}5 \\
12\end{array}$ & $\begin{array}{c}0 \\
10^{*}\end{array}$ & $\begin{array}{l}16.5 \pm 0.1 \\
16.9 \pm 0.2\end{array}$ & $16 \cdot 8 \pm 0 \cdot 3$ \\
\hline
\end{tabular}

Firstly, it would appear probable that there is indeed a local interrelationship between the ovaries and uterus. The breaking of this link by surgical means would reduce but not eliminate the luteolytic influence of the uterus on the corpora lutea: total hysterectomy is necessary to eliminate luteal involution completely in the cyclical ewe. The mechanism responsible for the prompt arrest of luteal involution after uterine extirpation during the latter stages of the cycle could most easily be explained in terms of a direct luteolytic action of the uterus on the corpus luteum.

A second explanation could be that surgical procedures associated with unilateral hysterectomy might result in damage to the ovarian vascular supply. Ipsilateral hysterectomy would thus affect the corpus luteum more markedly than the removal of the contralateral uterine horn. However, such damage might well be expected to shorten rather than to extend the life-span of the corpus luteum. Moreover, current work involving the transfer of viable sheep embryos to various portions of the uterus has resulted in strong evidence of a local interdependence between the uterus, the embryo and the corpus luteum. 
We are grateful to $\operatorname{Dr} T$. R. R. Mann for reading this manuscript and to Mr H. Strange for skilled technical assistance.

\section{REFERENCES}

BLANd, K. P. \& Donovan, B. T. (1965) Local control of luteal function by the uterus of the guinea pig. Nature, Lond. 207, 867.

Du Busson, F. Du Messit (1961) Regression unilaterale des corps jaunes après hysterectomie partielle chez la truie. Annls Biol. anim. Biochim. Biophys. 1, 105.

Fischer, T. V. (1965) Local uterine inhibition of the corpus luteum in the guinea pig. Anat. Rec. $151,350$.

Moor, R. M. \& Rowson, L. E. A. (1964) Influence of the embryo and uterus on luteal function in the sheep. Nature, Lond. 201, 522.

Rowson, L. E. A. \& MooR, R. M. (1964) Effect of partial hysterectomy on the length of the dioestrous interval in sheep. Vth int. Congr. Anim. Reprod. and Artificial Insemination, Trento, vol. II, p. 394.

Wiltbank, J. N. \& CAsida, L. E. (1956) Alteration of ovarian activity by hysterectomy. F. Anim. Sci. $15,134$. 